Gut, 1979, 20, 291-299

\title{
Comparison of oral feeding of peptide and amino acid meals to normal human subjects
}

\author{
D. B. A. SILK ${ }^{1}$, Y. C. CHUNG, K. L. BERGER, K. CONLEY, M. BEIGLER, \\ M. H. SLEISENGER, G. A. SPILLER, AND Y. S. KIM
}

From the Gastrointestinal Research Laboratory, Veterans Administration Hospital, San Francisco,California, School of Medicine, San Francisco, California, and Department of Nutritional Science, Syntex Research, Palo Alto, California, USA

SUMMARY Intestinal perfusion studies performed in man have suggested that amino acid nitrogen may be absorbed more rapidly from peptides than free amino acids. The aim of the present study was to compare the effects of the oral administration of peptides and free amino acids. Two isonitrogenous liquid test meals, one containing $50 \mathrm{~g}$ of a partial enzymic hydrolysate of fish protein in which approximately $80 \%$ of the nitrogen content was present as small peptides (peptide meal), and the other a mixture of free amino acids (amino acid meal) the composition and molar pattern of which simulated that of the peptide meal, were administered on separate occasions to six normal subjects intubated with a triple lumen tube. Both meals contained the reference marker polyethylene glycol. Fractional absorption of amino acid residues one and two hours after ingestion of the two meals was similar at three intestinal locations situated 120,160 , and $200 \mathrm{~cm}$ from the mouth of each subject, and at two hours $73.8 \%$ and $72.0 \%$ of the amino acid residues had been absorbed respectively by the time the contents of the peptide and amino acid meals reached the middle sampling port of the tube. The total sum of individual amino acid increments in plasma was significantly greater 30 minutes $(P<0.025)$ and one hour $(P<0.05)$ after ingestion of the peptide than amino acid meals. By three hours the total area under the two plasma curves was similar. Normal human subjects thus appeared to be capable of assimilating orally administered mixtures of peptides and free amino acids with equal efficiency. Secretion of fluid into the lumen of the upper small intestine, assessed by reference to dilution of the polyethylene glycol, was less after ingestion of the peptide meal. In clinical situations characterised by fluid and electrolyte malabsorption consideration might be given to using small peptides rather than free amino acids as the nitrogen source in nutritional diets.

The processes involved in the absorption of the final products of luminal proteolysis in the human small intestine are complex. Amino acids on release into free solution are absorbed by at least four group specific carrier-mediated active transport systems (Saunders and Isselbacher, 1966; Gray and Cooper, 1971). In addition to these transport systems, a separate system capable of mediating the transport of unhydrolysed dipeptides and tripeptides across the microvillous membrane into the mucosal cell has now been characterised (Silk, 1974; Matthews, 1975; Adibi, 1976; Matthews and Adibi, 1976). In

${ }^{1}$ Present address: Department of Gastroenterology, Central Middlesex Hospital, Acton Lane, London NW10.

Received for publication 9 October 1978 the studies of peptide transport which to date have mostly been carried out using segmental in vivo perfusion techniques, a consistent finding has been that on a molar basis amino acid residues are absorbed faster when presented to the intestinal mucosa as peptides rather than in the free form (Adibi, 1971; Hellier et al., 1972; Cook, 1973; Silk et al., 1974a; Adibi et al., 1975). This has prompted suggestions that there might be nutritional advantages if small peptides rather than free amino acids were used as the nitrogen source in chemically defined, elemental diets now currently being used as a means of providing oral alimentation to patients (Silk et al., 1973, 1975; Matthews, 1975; Matthews and Adibi, 1976).

The techniques of steady state intestinal perfusion 
used in the studies of amino acid and peptide transport referred to above, while permitting important conclusions to be drawn about the mechanisms involved in transport have, however, provided relatively little information concerning comparisons of the overall handling of amino acid and peptide mixtures by the intact human intestine. The aim of the present study was therefore to compare the effect of oral feeding of liquid peptide and free amino acid test meals of identical amino acid composition. The two isonitrogenous liquid test meals, one of which contained $50 \mathrm{~g}$ of a partial enzymic hydrolysate of fish protein in which approximately $80 \%$ of the nitrogen content was present as small peptides (peptide meal) and the other a mixture of free amino acids (amino acid meal) in which the composition and molar pattern simulated that of the peptide meal, were administered orally on separate occasions to six normal subjects intubated with a triple lumen tube. Comparisons were made of the plasma free amino acid profiles, and intestinal free and peptide bound amino acid profiles in response to ingestion of the two meals. Both meals contained unlabelled polyethylene glycol (PEG) so that in addition to the above it was possible to derive an estimate of the extent of amino acid absorption from the two meals as well as assessing proximal gastrointestinal fluid secretion in response to meal ingestion.

\section{Methods}

\section{COMPOSITION OF TEST MEALS}

The peptide meal was prepared by dissolving $50 \mathrm{~g}$ of a soluble, palatable, partial enzymic hydrolysate of fish protein in $450 \mathrm{ml}$ of distilled water containing unlabelled PEG $(4 \mathrm{~g} / \mathrm{l})$ and adjusting the final volume to $600 \mathrm{ml}$. The techniques used in the synthesis of the fish protein hydrolysate have been described fully elsewhere (Perini, 1975). Briefly, a fish protein concentrate was incubated for a total of 18 hours at alkaline $\mathrm{pH}(8.5 \pm 0.2)$ with a mixture of bovine or porcine pancreatic enzymes in the presence of toluene and chloroform, the temperature of the reaction mixture being maintained at $43 \cdot 3^{\circ} \mathrm{C}$. After digestion the $\mathrm{pH}$ was then adjusted to $\mathrm{pH} 7 \cdot 0 \pm 0 \cdot 1$ by addition of aqueous phosphoric acid, and the enzyme activity permanently deactivated by heating to $61.7^{\circ} \mathrm{C}$. The mixture was then filtered using the formed precipitate of monobasic calcium phosphate and dibasic calcium phosphate as the filter aid. The resultant filtrate containing peptides and free amino acids was then mixed with particulate activated charcoal and refiltered. The protein hydrolysate was finally recovered in powder form by evaporation followed by freeze drying.

The approximate size of the peptides in the peptide meal was estimated by gel filtration. Then $0.5 \mathrm{ml}$ of a $5 \mathrm{~g} / \mathrm{dl}$ solution of the fish protein hydrolysate prepared in $0.1 \mathrm{M}$ acetic acid (final $\mathrm{pH} \mathrm{4.4)}$ was loaded onto a column $(1.5 \times 91.3 \mathrm{~cm})$ packed with Bio-Gel P-6 (200-400 mesh, Bio-Rad Laboratories, Richmond, Ca) and eluted with $0 \cdot 1 \mathrm{M}$ acetic acid (pH 2.9) at a flow rate of $0.5 \mathrm{ml} / \mathrm{min}$. Two millilitre fractions, collected at room temperature, were monitored at $220 \mathrm{nM}$ on a Beckman model 25 spectrophotometer (Beckman Instruments, Palo Alto, $\mathrm{Ca}$ ) and pooled according to approximate molecular weights. None of the sample eluted corresponded to a molecular weight of greater than 1500. Eight per cent eluted in fractions corresponding to the molecular weight equivalent to peptide chain lengths of four to 14 amino acid residues. Seventytwo per cent eluted in fractions corresponding to the molecular weight equivalent to peptide chain lengths of two to four amino acid residues and $20 \%$ of the sample eluted in fractions corresponding to the molecular weight of free amino acids.

A quantitative analysis of the amino acid composition of the peptide meal was performed after the peptides present had been completely hydrolysed to their constituent amino acids (Table 1). Aliquots of the peptide meals were mixed with 1 vol of $6 \mathrm{~N} \mathrm{HCl}$ and heated for 17 hours at $100^{\circ} \mathrm{C}$ under reflux conditions. At the end of acid hydrolysis the samples were flash evaporated to dryness, reconstituted in $0.2 \mathrm{~N}$ sodium citrate buffer, $\mathrm{pH} 2 \cdot 2$, and the concentrations of free amino acids measured by ion exchange chromatography using a Beckman 119 amino acid analyser (Beckman Instruments, Palo Alto, $\mathrm{Ca}$ ).

The amino acid meals were prepared by dissolving

Table 1 Amino acid composition ( $\mu \mathrm{mol} / \mathrm{ml}$ ) of the liquid test meals

\begin{tabular}{|c|c|c|}
\hline Amino acid & Peptide meal* & Amino acid meal $\dagger$ \\
\hline $\begin{array}{l}\text { Aspartic acid } \\
\text { Threonine } \\
\text { Serine } \\
\text { Glutamic acid } \\
\text { Proline } \\
\text { Cysteine } \\
\text { Glycine } \\
\text { Alanine } \\
\text { Valine } \\
\text { Methionine } \\
\text { Isoleucine } \\
\text { Leucine } \\
\text { Tyrosine } \\
\text { Phenylalanine } \\
\text { Tryptophan } \\
\text { Lysine } \\
\text { Histidine } \\
\text { Arginine }\end{array}$ & $\begin{array}{r}63 \cdot 4 \\
32 \cdot 8 \\
28 \cdot 2 \\
83 \cdot 7 \\
22 \cdot 8 \\
- \\
48 \cdot 1 \\
55 \cdot 5 \\
51 \cdot 3 \\
25 \cdot 2 \\
38 \cdot 7 \\
51 \cdot 5 \\
9 \cdot 8 \\
29 \cdot 6 \\
2 \cdot 0 \\
54 \cdot 7 \\
13 \cdot 3 \\
30 \cdot 4\end{array}$ & $\begin{array}{r}66 \cdot 9 \\
41 \cdot 8 \\
21 \cdot 5 \\
100 \cdot 6 \\
24 \cdot 2 \\
2 \cdot 4 \\
48 \cdot 9 \\
60 \cdot 2 \\
55 \cdot 8 \\
26 \cdot 1 \\
43 \cdot 9 \\
53 \cdot 1 \\
9 \cdot 4 \\
27 \cdot 4 \\
2 \cdot 9 \\
51 \cdot 5 \\
15 \cdot 4 \\
36 \cdot 2\end{array}$ \\
\hline
\end{tabular}

* Mean of eight replicate analyses as determined after acid hydrolysis of the peptide fraction.

†Mean of three replicate analyses of prepared liquid test meal contents. 
$53.5 \mathrm{~g}$ of a preweighed and premixed batch of amino acids in $450 \mathrm{ml}$ distilled water containing PEG $(4 \mathrm{~g} / \mathrm{l})$ and adjusting the volume to $600 \mathrm{ml}$. The pattern and molar concentrations of free amino acids were formulated to simulate those present in the peptide meal. The final concentrations present determined by analysis using ion exchange chromatography are also shown in Table 1 . Higher concentrations of tryptophan, cysteine, and threonine were included in the amino acid meal because acid hydrolysis, performed during the analysis of the amino acid composition of the peptide meal, has an appreciable destructive effect on these compounds (Rees, 1946; Adibi and Mercer, 1973).

\section{EXPERIMENTAL TECHNIQUE}

The peptide and amino acid meals were administered orally on separate occasions to six normal adult volunteers (age 23-31 years), who before each of the two studies had been intubated with a triple lumen tube. All aspects of the experimental protocol were approved by the Committee for the Protection of Human Subjects in Experiments, University of California, San Francisco, and written consent was obtained from each subject before participation in the study. On the afternoon before each feeding experiment subjects were fasted for four hours and then intubated with the tube. Two hours later the position of the tube was checked radiologically to ensure that the mercury bag at the distal end of the tube was positioned in the duodenum. Subjects were then allowed access to a liquid diet until $1 \hat{i}$ p.m., and the tube allowed to progress distally through the small intestine. The final position of the tube was checked radiologically between 8 and 9 a.m. on the morning of each experiment to ensure that the proximal, middle, and distal sampling ports were situated 120,160 , and $200 \mathrm{~cm}$ respectively from the mouth of each subject. One or other of the two liquid test meals was then consumed by each subject over a period of five to 10 minutes. The order of administration of the two meals was randomised.

Before and at regular intervals 30 minutes, one, two, and three hours after ingestion of the meals $10 \mathrm{ml}$ venous blood was obtained and collected into heparinised tubes which were immediately centrifuged at $800 \mathrm{~g}$ for 10 minutes. The plasma was separated and deproteinised by addition of $1 \mathrm{vol}$ $6 \mathrm{~g} / \mathrm{dl}$ sulphosalicylic acid, the latter solution containing norleucine $(0.8 \mathrm{mmol} / \mathrm{l})$ as an internal standard. After mixing, the protein-free filtrate was separated by centrifugation at $800 \mathrm{~g}$ for another 10 minutes, and stored at $-20^{\circ} \mathrm{C}$. The concentration of 13 free amino acids (threonine, serine, glutamic acid, glutamine, proline, glycine, alanine, valine, methionine, isoleucine, leucine, tyrosine, and phenylalanine) were measured in fasting and postprandial protein free plasmas by ion exchange chromatography using a Beckman $120 \mathrm{C}$ amino acid analyser (Beckman Instruments, Palo Alto, $\mathrm{Ca}$ ).

Intestinal contents were obtained by simple syphonage from the proximal sampling port of the tube 30 minutes, one, two, and three hours after ingestion of the meals. Whenever possible, samples were also obtained one, two, and three hours after ingestion of the meals from the middle and distal sampling ports. It was not always possible to obtain these samples by simple syphonage alone and, when this was the case, intestinal contents were aspirated into $10 \mathrm{ml}$ syringes. Immediately after sampling, intestinal contents were placed into glass tubes positioned in a mixture of dry ice and ethanol to prevent in vitro hydrolysis of protein and peptides by both pancreatic proteolytic enzymes and intraluminal peptidases (Silk et al., 1976). At the end of each feeding experiment the temperature of the intestinal samples was raised to $4^{\circ} \mathrm{C}$, and after thorough mixing the samples were centrifuged at $800 \mathrm{~g}$ for 10 minutes at $0-4^{\circ} \mathrm{C}$. The resultant supernatants were divided into two aliquots. In four studies, the first was used for quantitative analysis of the intestinal free and peptide bound amino acid profiles and was immediately transferred to a tube positioned in a water bath maintained at $90^{\circ} \mathrm{C}$ in order permanently to deactivate pancreatic proteolytic and intraluminal peptidase enzyme activities. After 15 minutes, samples were cooled at room temperature and the protein content removed by addition of $1 \mathrm{vol} 6 \mathrm{~g} / \mathrm{dl}$ sulphosalicyclic acid which contained norleucine $(0.8 \mathrm{mmol} / \mathrm{l})$ as an internal standard. After mixing, the protein-free filtrate was separated by centrifugation at $800 \mathrm{~g}$ for 10 minutes, and stored at $-20^{\circ} \mathrm{C}$. Before analysis, the protein-free filtrate was divided into two fractions: one fraction was used for determination of free amino acid content by ion exchange chromatography using the Beckman 119 amino acid analyser; the other fraction was used for determination of amino acids in the peptide form. Peptides present in each sample were hydrolysed to their free amino constituents using $6 \mathrm{~N} \mathrm{HCl}$ as described above, and the resultant free amino acid content quantified by the ion exchange chromatography technique. The concentration of amino acids in peptide form was the difference between the concentration of the same amino acid in the protein-free filtrate after and before acid hydrolysis (Adibi and Mercer, 1973). PEG was found to be absent from some intestinal samples obtained three hours after ingestion of the peptide meal, indicating that absorption of the meal from the proximal jejunum had been completed by three hours. Only one and two hours intestinal samples were therefore analysed for free 
and peptide bound amino acids.

The second aliquot of each intestinal sample was stored at $-20^{\circ} \mathrm{C}$ until required for analysis of PEG content which was measured chemically using a technique described previously (Malawer and Powell, 1967).

\section{CALCULATION OF RESUlTS}

The fractional absorption (A) of each individual amino acid residue at the three intestinal locations (120, 160, and $200 \mathrm{~cm}$ from the mouth) was calculated from the formula (Borgstrom et al., 1957):

$$
A=\frac{A_{I}}{A_{M}} \times 100 \%
$$

where $A_{I}$ is the amount ( $\mu \mathrm{mol}$ ) of each individual amino acid residue as determined after acid hydrolysis, in protein-free intestinal samples per unit (mg) PEG in the same sample, and $A_{M}$ is the amount of the same amino acid residue $(\mu \mathrm{mol})$ per unit $(\mathrm{mg})$ PEG in the test meal.

The total fractional absorption of the amino acid residues was calculated using the same formula, except that $A_{I}$ is the sum of the individual amino acid residues $(\mu \mathrm{mol})$ per unit $(\mathrm{mg})$ PEG in the intestinal samples and $A_{M}$ is the sum of the individual amino acid residues $(\mu \mathrm{mol})$ per unit $(\mathrm{mg})$ PEG in the test meal.

The paired $t$ test was used for statistical analysis of plasma amino acid increments. The unpaired $t$ test was used for statistical analysis of intestinal amino acid profiles, PEG data, and fractional absorption data.

\section{Results}

FREE AMINO ACIDS IN PLASMA

The total sum of the individual amino acid increments over the time course of the experiments are summarised in Fig. 1. The total increments were greater 30 minutes and one hour after ingestion of the peptide meal $(2 \cdot 10 \pm$ SEM 0.27, $2 \cdot 21 \pm 0.37$ $\mathrm{mmol} / \mathrm{l})$ than after ingestion of the amino acid meal $(1.29 \pm 0.14,1.69 \pm 0.21 \mathrm{mmol} / \mathrm{l} ; \mathrm{P}<0.025$, $P<0.05$ respectively). At the two hour interval the total increments were very similar. Although not statistically significant, the mean total increment was greater three hours after ingestion of the amino acid meal $(1.00 \pm 0.30 \mathrm{mmol} / \mathrm{l})$ than after the peptide meal $(0.81 \pm 0.13 \mathrm{mmol} / \mathrm{l})$ and by three hours the area beneath the two plasma amino acid curves in Fig. 1 were the same.

At 30 minutes, increments of five individual amino acids, glutamic acid $(P<0.05)$, alanine $(P<0.05)$, methionine $(P<0.025)$, isoleucine $(P<0.05)$, and phenylalanine $(P<0.05)$ were all greater after

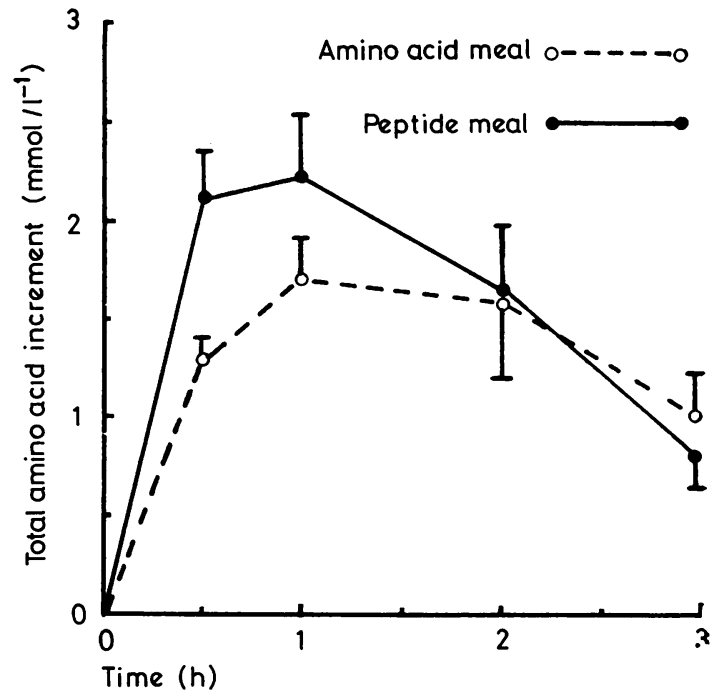

Fig. 1 Total increments over fasting levels of free amino acids in plasma at regular intervals after oral ingestion of the peptide and amino acid meals. Values are the mean $\pm S E$ in six subjects.

ingestion of the peptide than amino acid meal. At one hour this was the case only for two, serine $(P<0.05)$ and glycine $(P<0.05)$. By two hours the tyrosine $(\mathrm{P}<0.025)$ and phenylalanine $(\mathrm{P}<0.05)$ increments were greater after ingestion of the peptide meal, but the methionine increment was now greater after ingestion of the amino acid meal ( $P<0.05)$. At three hours there was no significant difference between the increments of any of the 13 amino acids after ingestion of the two meals.

To determine whether there was any relationship between the amino acid composition of the test meals and the increments in the plasma levels of individual plasma amino acids, the increments for individual plasma amino acids at each time period were plotted against the amino acid composition of the materials ingested expressed as a molar basis relative to histidine. As proportions of the ingested glutamic acid were aminated and transaminated by the intestinal mucosa, entering the blood as glutamine and alanine respectively, glutamic acid, glutamine and alanine were excluded from the plots. A significant correlation was found for both the peptide meal $(r=0.76, \mathrm{P}<0.05)$ and amino acid meal $(r=0.79, \mathrm{P}<0.01)$ at 30 minutes and at one hour (peptide meal: $r=0.81, \mathrm{P}<0.01$; amino acid meal: $r=0.80, \mathrm{P}<0.01$ ). At two hours a significant correlation was only found for the peptide meal $(r=0.78, \mathrm{P}<0.01)$ and at three hours no significant. correlation was found for either material. 


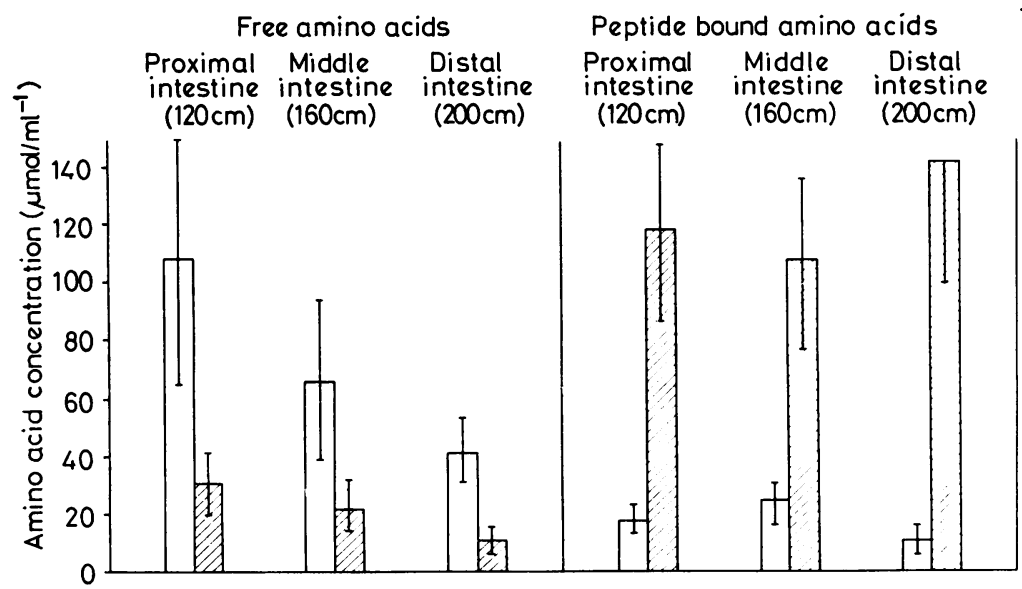

Fig. 2 Concentrations of free amino acids and peptide bound amino acids detected in gut contents aspirated via the proximal, middle and distal sampling ports two hours after ingestion of the amino acids (clear histograms) and peptide meals (hatched histograms). Values are mean $\pm S E$ in four subjects.
INTESTINAL PROFILES OF FREE AND PEPTIDE BOUND AMINO ACIDS

The free and peptide bound amino acid profiles of the intestinal contents aspirated one and two hours after ingestion of the two meals were similar, so for economy of presentation the results are detailed only for the two hour interval.

Intestinal contents sampled after ingestion of the peptide and free amino acid meal both contained free and peptide bound amino acids (Fig. 2). At all three intestinal locations the total peptide bound amino acid concentrations were greater after ingestion of the peptide than the amino acid meal (P $<0.01, \mathrm{P}<0.05, \mathrm{P}<0.05$ for proximal, middle, and distal contents respectively). There was a trend towards greater total concentrations of free amino acids after ingestion of the amino acid meal, but because of the scatter of results, particularly in proximal contents, these differences reached statistical significance only in the distal intestine (P $<0.025$ ).

With respect to the 16 individual peptide bound amino acids, mean values of all were higher after ingestion of the peptide than amino acid meal. In the proximal contents differences were significant only for serine $(P<0.025)$, glutamic acid $(P<0.05)$, glycine $(P<0.05)$, and valine $(P<0.05)$. However, in the middle intestinal contents the differences were significant for all but proline, lysine, histidine, and arginine and in the distal intestinal contents significance at the $5 \%$ level or less was reached for 14 . Of the two others no peptide bound glutamic acid or methionine could be detected after ingestion of the amino acid meal, whereas $26.2 \pm$ SE 8.7 and $7.4 \pm 5.5 \mu \mathrm{mol} / \mathrm{ml}$ respectively were detected after ingestion of the peptide meal.

Throughout the small intestine there was considerable variation in the concentration of free amino acids after ingestion of both meals. Without exception, the mean of the concentrations of all 16 amino acids at each sampling site was greater after ingestion of the amino acid than peptide meal, but statistical significance was reached only for aspartic acid (proximal and distal intestine, $P<0.05$; middle intestine, $\mathrm{P}<0.025$ ) and glutamic acid (proximal intestine, $P<0.05$ ).

The site of sampling had little effect on the concentrations of peptide bound amino acids after ingestion of the two meals. Thus the total concentrations of peptide bound amino acids in the proximal, middle, and distal contents were 117.6 $\pm 30 \cdot 8$, $107 \cdot 4 \pm 28 \cdot 9$, and $141 \cdot 6 \pm 42 \cdot 1 \mu \mathrm{mol} / \mathrm{ml}$, respectively. In contrast, there was a tendency for the concentration of free amino acids to decrease by the time the contents of the two meals had reached the distal sampling port of the tube (total concentrations of free amino acids after ingestion of the amino acid meal, $107 \cdot 5 \pm 42 \cdot 6,66 \cdot 3 \pm 27 \cdot 0,41 \cdot 0 \pm 12.5$ $\mu \mathrm{mol} / \mathrm{ml}$ proximal, middle, and distal contents respectively).

To determine whether there was any relationship between the amino acid profiles of the ingested meals and the intestinal contents, the concentrations of amino acids (free and peptide bound) detected in intestinal contents aspirated at the three sampling ports were plotted against the amino acid composition of the materials ingested expressed on a molar basis relative to histidine. A significant correlation was found for the amino acid meal $(r=0.89$, $\mathrm{P}<0.001 ; r=0.70, \mathrm{P}<0.01 ; r=0.57, \mathrm{P}<0.05)$ and the peptide meal $(r=0.54, \mathrm{P}<0.05 ; r=0.75$, $\mathbf{P}<0.001 ; r=0.76, \mathrm{P}<0.001)$ at the proximal, middle, and distal locations respectively.

\section{INTESTINAL ABSORPTION OF AMINO ACID} RESIDUES

There was no significant difference at any time period between the fractional absorption of amino 


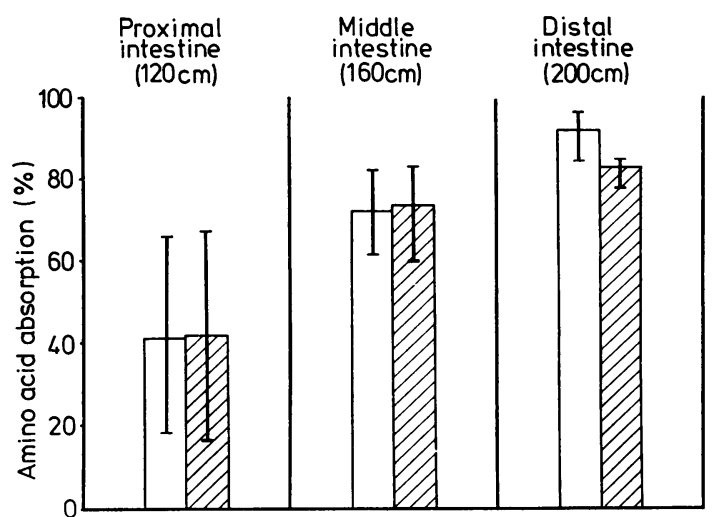

Fig. 3 Total fractional absorption of amino acid residues in the proximal, middle, and distal small intestine two hours after ingestion of the amino acid (clear histograms) and peptide meals (hatched histograms). Values are mean $\pm S E$ in four subjects.

acid residues from the two meals at any of three intestinal locations studied (Fig. 3). Absorption values, calculated after complete acid hydrolysis of deproteinised intestinal contents, showed that at two hours $41.8 \pm$ SE $23.9 \%$ and $41.9 \pm 25.3 \%$ of the total amino acid content of the amino acid and peptide meals had disappeared from the gut lumen by the time the liquid test meals had reached the proximal sampling port of the tube situated $120 \mathrm{~cm}$ from the mouth of each subject. Nearly threequarters of the total amino acid content of the amino acid and peptide meals $(72.0 \pm 10.3,73.8 \pm$ $8.6 \%$ respectively) had disappeared from the gut lumen by the time the middle sampling port was reached, which indicates that the distal half of the small intestine was not a significantly important site for absorption of free and peptide amino acids in the present study.
INTESTINAL FLUID SECRETION

Table 2 shows that after ingestion of the amino acid meal the PEG concentrations in proximal contents were significantly lower than in the meal itself $(0.5 \mathrm{~h}$, $\mathrm{P}<0.001 ; 1 \mathrm{~h}, \mathrm{P}<0.01$; $2 \mathrm{~h}, 3 \mathrm{~h}, \mathrm{P}<0.001)$ indicating that the meal contents had been considerably diluted by the time that they had reached the proximal sampling port of the tube. After ingestion of the peptide meal the differences in the PEG concentrations of the meal and intestinal contents were less marked and did not reach significance at two hours $(0.5,1,3 \mathrm{~h}, \mathrm{P}<0.05)$, which suggests that less proximal gastrointestinal fluid secretion occurred in response to oral ingestion of the peptide meal (osmolality $476 \mathrm{mOsm} / \mathrm{kg}$ ) than the amino acid meal (osmolality $895 \mathrm{mOsm} / \mathrm{kg}$ ).

At the site of the middle sampling port, the PEG concentrations in intestinal contents sampled one and two hours after ingestion of the amino acid meal remained significantly lower than in the meals themselves $(\mathrm{P}<0.05, \mathrm{P}<0.01)$, but by three hours the intestinal PEG concentration had risen $(6.45 \pm$ $1.67 \mathrm{mg} / \mathrm{ml}$ ) and was similar to that in the ingested meal $(6.90 \pm 0.57)$. In contrast, there was no significant difference between the initial PEG concentrations in the peptide test meals and the concentrations in middle intestinal contents samples one, two, and three hours after meal ingestion. With the exception of the distal intestinal contents sampled one hour after ingestion of the peptide meal, which had a lower PEG concentration $(3 \cdot 2 \pm 0 \cdot 16 \mathrm{mg} / \mathrm{ml})$ than the ingested meal $(6.35 \pm 0.83, \mathrm{P}<0.01)$, the PEG concentrations in all other distal intestinal contents were similar or greater than in the respective amino acid and peptide meals.

\section{Discussion}

The results show that greater plasma amino acid increments occurred half and one hour after inges-

Table 2 Polyethylene glycol (PEG) concentrations in ingested test meals and intestinal contents $(\mathrm{mg} / \mathrm{ml}, \mathrm{mean} \pm S E)$

\begin{tabular}{|c|c|c|c|c|c|c|c|}
\hline \multirow{2}{*}{$\begin{array}{l}\text { Intestinal location } \\
(\mathrm{cm} \text { from mouth) }\end{array}$} & \multirow{2}{*}{$\begin{array}{l}\text { Time after } \\
\text { meal ingestion } \\
(h)\end{array}$} & \multicolumn{3}{|c|}{ Amino acid meal } & \multicolumn{3}{|c|}{ Peptide meal } \\
\hline & & $\begin{array}{l}\text { Number of } \\
\text { subjects }\end{array}$ & Test meal & $\begin{array}{l}\text { Intestinal } \\
\text { contents }\end{array}$ & $\begin{array}{l}\text { Number of } \\
\text { subjects }\end{array}$ & Test meal & $\begin{array}{l}\text { Intestinal } \\
\text { contents }\end{array}$ \\
\hline Proximal $(120 \mathrm{~cm})$ & $\begin{array}{l}0.5 \\
1 \\
2 \\
3\end{array}$ & $\begin{array}{l}5 \\
6 \\
6 \\
6\end{array}$ & $\begin{array}{l}7.06 \pm 0.47 \\
7.17 \pm 0.40 \\
7 \cdot 18 \pm 0.40 \\
7.18 \pm 0.40\end{array}$ & $\begin{array}{l}2.64 \pm 0.37 \\
3.33 \pm 0.81 \\
3.05 \pm 0.50 \\
3.35 \pm 0.72\end{array}$ & $\begin{array}{l}5 \\
6 \\
4 \\
4\end{array}$ & $\begin{array}{l}6.68 \pm 0.72 \\
6.96 \pm 0.65 \\
7.5 \pm 0.50 \\
6.92 \pm 0.96\end{array}$ & $\begin{array}{l}3.38 \pm 1.16 \\
4.55 \pm 0.77 \\
4.8 \pm 1.42 \\
2.92 \pm 0.83\end{array}$ \\
\hline Middle $(160 \mathrm{~cm})$ & $\begin{array}{l}1 \\
2 \\
3\end{array}$ & $\begin{array}{l}5 \\
6 \\
4\end{array}$ & $\begin{array}{l}7.06 \pm 0.47 \\
7.18 \pm 0.40 \\
6.90 \pm 0.57\end{array}$ & $\begin{array}{l}4.72 \pm 0.97 \\
4.26 \pm 0.88 \\
6.45 \pm 1.67\end{array}$ & $\begin{array}{l}5 \\
6 \\
5\end{array}$ & $\begin{array}{l}6.82 \pm 0.78 \\
6.96 \pm 0.65 \\
7.14 \pm 0.77\end{array}$ & $\begin{array}{l}7 \cdot 10 \pm 1 \cdot 28 \\
8 \cdot 83 \pm 2 \cdot 48 \\
7 \cdot 12 \pm 2 \cdot 47\end{array}$ \\
\hline Distal $(200 \mathrm{~cm})$ & $\begin{array}{l}1 \\
2 \\
3\end{array}$ & $\begin{array}{l}5 \\
5 \\
4\end{array}$ & $\begin{array}{l}7.08 \pm 0.47 \\
7.16 \pm 0.49 \\
7.02 \pm 0.61\end{array}$ & $\begin{array}{l}5.06 \pm 0.89 \\
8.40 \pm 1.90 \\
6.92 \pm 2.16\end{array}$ & $\begin{array}{l}4 \\
5 \\
4\end{array}$ & $\begin{array}{l}6.35 \pm 0.83 \\
6.82 \pm 0.78 \\
7.00 \pm 0.98\end{array}$ & $\begin{array}{r}3 \cdot 2 \pm 0 \cdot 16 \\
7 \cdot 36 \pm 2 \cdot 71 \\
11 \cdot 2 \pm 3 \cdot 69\end{array}$ \\
\hline
\end{tabular}


tion of the peptide than the amino acid test meal. A recent study has shown that the same two liquid test meals used in the present study empty from the stomach of normal subjects at similar rates $(J$. N. Hunt, 1978, personal communication) which suggests that during the first hour of our experiments greater amounts of peptide bound than free amino acids were absorbed from the small intestine. Caution is required, however, when interpreting the possible clinical or nutritional significance of these data, as Fig. 1 shows that the total areas under the two plasma amino acid curves were the same, indicating that by three hours similar amounts of nitrogen had been absorbed from the two meals.

Suggestions have been made in the literature that the pattern of appearance of amino acids in peripheral plasma is unrelated to the amino acid composition of the nitrogenous material ingested (Frame, 1958; Yearick and Nadeau, 1967) either because of the influence of tissue uptake and release of amino acids, especially by the liver (Miller, 1962) or because ingested protein is mixed with several times its mass of endogenous protein (Nasset, 1965). Our results, which are in agreement with those of Adibi and Mercer (1973) and Marrs et al. (1975), do not support this belief, as significant correlations were found between the amino acid composition of the two test meals and the extent of increases in the concentrations of amino acids in peripheral plasma.

Moreover, if large amounts of endogenous protein had been secreted into the gastrointestinal tract in response to oral ingestion of the meals, then after intraluminal hydrolysis high concentrations of free and peptide-bound amino acids of endogenous origin should have been detected in the aspirated gut contents. On analysis of the intestinal aspirates the presence of high concentrations of endogenous peptide would have become apparent after ingestion of the exogenous free amino acid meal and endogenous free amino acids after ingestion of the peptide meal. Figure 2 shows that this was clearly not the case, as only low concentrations of free and peptide bound amino acids were detected after ingestion of the peptide and amino acid meals respectively. This suggests that the magnitude of secretion of endogenous protein is not as large as has been supposed.

The significant differences in the plasma amino acid increments observed after oral ingestion of the amino acid and peptide meals were not reflected by similar differences in fractional absorption rates of the amino acid residues at any time period during their passage through the small intestine (Fig. 3). Furthermore, the similarity of the fractional absorption values from the two meals contrasts with the results of recent intestinal perfusion experiments that have shown greater absorption of amino acid residues from four partial enzymic hydrolysates of protein (including the preparation used in the present study) than from their equivalent free amino acid mixtures (Silk et al., 1973, 1975; Fairclough, 1978).

The most likely reason for these discrepancies is a methodological one. Thus, Levitt (1977) has recently criticised the use of PEG as a reference marker in 'non steady-state' conditions such as was used in the present study and, based upon mathematical models of marker dilution, has pointed out that precise quantitative data concerning solute absorption can be obtained only if PEG is either perfused at a fast flow rate through the small intestine or large volumes of intestinal contents are sampled over short time periods. While we fully agree with his comments, neither approach could be adopted in the present study for technical reasons, and failure to adopt these suggestions may have led to the marked variation in fractional absorption values found in the proximal small intestine (Fig. 3), the site at which the meal contents are mixed with gastric, biliary, pancreatic, and intestinal secretions.

When comparing the absorption values from the two meals it should also be borne in mind that, although the volume and nitrogen content of the two meals were kept the same so that the experimental findings should have some relevance to the clinical use of 'chemically defined, elemental' diets, the osmolalities were markedly different. The lack of differences in absorption values could therefore be due to the different conditions in the intestinal lumen-for example, as the PEG data in Table 2 suggest, less fluid and electrolytes after ingestion of the peptide meal. It should be stressed, however, that the absolute sodium dependency of free amino acid and peptide transport in the human small intestine has yet to be demonstrated (Silk and Dawson, 1977).

Notwithstanding the methodological problems involved in the interpretation of the fractional absorption values, it is noteworthy that there was little variation in absorption values by the time the meal contents had reached the middle and distal sampling ports (Fig. 3). These results thus suggest that the two meals containing substantial quantities of nitrogen were absorbed predominantly in the proximal small intestine. Borgström et al. (1957) and Nixon and Mawer (1970) reached similar conclusions as a result of their studies of protein absorption. Adibi and Mercer (1973), however, implicated the ileum as an additional site of protein absorption.

A reference marker was not used in the above study and, as our findings in Table 2 show, distal small intestinal contents are more concentrated than proximal contents. The exclusion of a reference marker from liquid test meals in this type of study 
may therefore result in the importance of the ileum as an absorptive site being over-estimated.

Two recent surveys have indicated that up to $44 \%$ and $50 \%$ of hospital inpatients with medical and surgical disorders respectively have evidence of moderate to severe protein-calorie malnutrition (Bistrian et al., 1974, 1976). Although several commercially produced nutritional diets have now been marketed for the treatment of such patients, the optimal composition of the nitrogen source has not yet been established (Young et al., 1975). Our results suggest that, as long as gastrointestinal function is normal, partial enzymic hydrolysates of whole protein (consisting predominantly of small peptides) are likely to be assimilated as effectively as their respective free amino acid mixtures. As mentioned above, the PEG data (Table 2) suggest that more fluid was secreted into the lumen of the proximal intestine in response to ingestion of the hypertonic amino acid meal than the relatively hypotonic peptide meal. If the functional integrity of the small intestinal mucosa with respect to fluid and electrolyte absorption is impaired, as for example in untreated adult coeliac disease (Fordtran et al., 1967; Russell et al., 1972; Silk et al., 1974b), after massive intestinal resection (Leonard et al., 1967), or in patients who have had jejunoileal bypass operations for morbid obesity (Gazet et al., 1974; Geiss et al., 1976), then it might be advantageous to achieve satisfactory assimilation of orally administered nitrogen at the cost of as little intestinal secretion of fluid and electrolytes as possible. This being so, we suggest that consideration could be given to choosing a diet that contains peptides rather than free amino acids as the nitrogen source.

Finally, it should be appreciated that the characteristics of absorption of partial enzymic hydrolysates of protein will be determined not only by the nature of the protein chosen for hydrolysis but also by the conditions used for the hydrolysis procedure. The results of oral feeding experiments such as reported in this paper are thus likely to vary according to the particular protein hydrolysate tested. While intestinal perfusion studies have shown greater absorption of amino acids from all four partial enzymic hydrolysates of protein so far tested than from their respective free amino acid mixtures (Silk et al., 1973, 1975; Fairclough, 1978), the greatest difference was found for the partial enzymic hydrolysate of lactalbumin (Fairclough, 1978). It might be of interest, therefore, to repeat certain aspects of the present study, using instead of the fish protein hydrolysate a partial enzymic hydrolysate of lactalbumin.

D. B. A. Silk is grateful to the Medical Research Council of Great Britain for financial support during the course of this work, and for their continuing support in his present appointment. The authors are grateful to Linda Rimmer for editorial assistance during preparation of the manuscript. The work was supported in part by Public Health Service Grant AM-17938 from the National Institutes of Health of the USA.

\section{References}

Adibi, S. A. (1971). Intestinal transport of dipeptides in man: relative importance of hydrolysis and intact absorption. Journal of Clinical Investigation, 50, 2266-2275.

Adibi, S. A. (1976). Intestinal phase of protein assimilation in man. American Journal of Clinical Nutrition, 29, 205-215.

Adibi, S. A., and Mercer, D. W. (1973). Protein digestion in human intestine as reflected in luminal, mucosal and plasma amino acid concentrations after meals. Journal of Clinical Investigation, 52, 1586-1594.

Adibi, S. A., Morse, E. L., Masilamani, S. S., and Amin, P. M. (1975). Evidence for two different modes of tripeptide disappearance in human intestine, uptake by peptide carrier systems and hydrolysis by peptide hydrolases. Journal of Clinical Investigation, 56, 1355-1363.

Bistrian, B. R., Blackburn, G. L., Hallowell, E., and Heddle, R. (1974). Protein status of general surgical patients. Journal of the American Medical Association, 230, 858-862.

Bistrian, B. R., Blackburn, G. L., Vitale, J., Cochran, D., and Naylor, J. (1976). Prevalence of malnutrition in general medical patients. Journal of the American Medical Association, 235, 1567-1570.

Borgström, B. A., Dahlqvist, G., Lundh, G., and Sjövall, J. (1957). Studies of intestinal digestion and absorption in the human. Journal of Clinical Investigation, 36, 1521-1536.

Cook, G. C. (1973). Independent jejunal mechanisms for glycine and glycylglycine transfer in man in vivo. British Journal of Nutrition, 30, 13-19.

Fairclough, P. D. (1978). Jejunal Absorption of Water and Electrolytes in Man: the Effects of Amino Acids, Peptides and Saccharides. MD Thesis: University of London.

Fordtran, J. S., Rector, F. C., Locklear, T. W., and Ewton, M. F. (1967). Water and solute movement in the small intestine of patients with sprue. Journal of Clinical Investigation. 46, 287-298.

Frame, E. G. (1958). The levels of individual free amino acids in the plasma of normal man at various intervals after a high-protein meal. Journal of Clinical Investigation, 37, 1710-1723.

Gazet, J. C., Pilkington, T. R. E., Kalucy, R. S., Crisp, A. H., and Day, S. (1974). Treatment of gross obesity by jejunal bypass. British Medical Journal, 4, 311-314.

Geiss, D. M., Shields, S., and Watts, J. D. (1976). Reversibility of hepatic failure following jejunoileal bypass. Archives of Surgery, 111, 1362-1365.

Gray, G. M., and Cooper, H. L. (1971). Protein digestion and absorption. Gastroenterology, 61, 535-544.

Hellier, M. D., Holdsworth, C. D., McColl, I., and Perrett, D. (1972). Dipeptide absorption in man. Gut, 13, 965-969.

Leonard, A. S., Levine, A. S., Wittner, R. Buchwald, H., and Varco, R. L. (1967). Massive small-bowel resections. Archives of Surgery, 95, 429-435.

Levitt, M. D. (1977). Use of the constant perfusion technique in the non-steady state. Gastroenterology, 73, 1450-1454.

Malawer, S. J., and Powell, D. W. (1967). An improved turbidimetric analysis of polyethylene glycol utilizing an emulsifier. Gastroenterology, 53, 250-256.

Marrs, T. C., Addison, J. M., Burston, D., and Matthews, D. M. (1975). Changes in plasma amino acid concentrations 
in man after ingestion of an amino acid mixture simulating casein, and a tryptic hydrolysate of casein. British Journal of Nutrition, 34, 259-265.

Matthews, D. M. (1975). Intestinal absorption of peptides. Physiological Reviews, 55, 537-608.

Matthews, D. M., and Adibi, S. A. (1976). Peptide absorption. Gastroenterology, 71, 151-161.

Miller, L. L. (1962). The role of the liver and the non hepatic tissues in the regulation of free amino acid levels in the blood. In Amino Acid Pools. Edited by J. T. Holden. Associated Scientific Publishers: Amsterdam.

Nasset, E. S. (1965). Role of the digestive system in protein metabolism. Federation Proceedings, 24, 953-958.

Nixon, S. E., and Mawer, G. E. (1970). The digestion and absorption of protein in man. I. The site of absorption. British Journal of Nutrition, 24, 227-240.

Perini, F. (1975). Enzymatic Processes for Hydrolysing Proteins. United States Patent No. 3,928,630.

Rees, M. W. (1946). The estimation of threonine and serine in proteins. Biochemical Journal, 40, 632-640.

Russell, R. I., Allan, J. G., Gerskowitch, V. P., and Robertson, J. W. K. (1972). A study by perfusion technique of the absorption abnormalities in the jejunum in adult coeliac disease. Clinical Science, 42, 735-741.

Saunders, S. J., and Isselbacher, K. J. (1966). Intestinal absorption of amino acids. Gastroenterology, 50, 586-595.

Silk, D. B. A. (1974). Peptide absorption in man. Gut, 15, 494-501.

Silk, D. B. A., and Dawson, A. M. (1977). Intestinal absorption of carbohydrate and protein in man. Gastrointestinal
Physiology II. (International Review of Physiology, Vol. 12.) Edited by R. K. Crane. University Park Press: London. Silk, D. B. A., Kumar, P. J., Perrett, D., Clark, M. L., and Dawson, A. M. (1974b). Amino acid and peptide absorption in patients with coeliac disease and dermatitis herpetiformis. Gut, 15, 1-8.

Silk, D. B. A., Marrs, T. C., Addison, J. M., Burston, D., Clark, M. L., and Matthews, D. M. (1973). Absorption of amino acids from an amino acid mixture simulating casein and a tryptic hydrolysate of casein in man. Clinical Science and Molecular Medicine, 45, 715-719.

Silk, D. B. A., Marrs, T. C., Clegg, K. M., Addison, J. M., Burston, D., Clark, M. L., and Matthews, D. M. (1975). Jejunal absorption of an amino acid mixture simulating casein and an enzymic hydrolysate of casein prepared for oral administration to normal adults. British Journal of Nutrition, 33, 95-100.

Silk, D. B. A., Nicholson, J. A., and Kim, Y. S. (1976). Hydrolysis of peptides within lumen of small intestine. American Journal of Physiology, 231, 1322-1329.

Silk, D. B. A., Perrett, D., Webb, J. P. W., and Clark, M. L. (1974a). Absorption of two tripeptides by the human small intestine: a study using a perfusion technique. Clinical Science and Molecular Medicine, 46, 393-402.

Yearick, E. S., and Nadeau, R. G. (1967). Serum amino acid response to isocaloric test meals. American Journal of Clinical Nutrition, 20, 338-344.

Young, E. A., Heuler, N., Russell, P., and Weser, E. (1975). Comparative nutritional analysis of chemically defined diets. Gastroenterology, 69, 1338-1345. 